\title{
1. Historical development of the jus ad bellum
}

\section{$1.1 \quad$ INTRODUCTION}

Throughout the course of human history, political communities have waged war as a means through which to protect and pursue their interests. At the same time, history reveals that these communities have implemented rules setting out the circumstances in which recourse to war is permissible. ${ }^{1}$ With this in mind, the objective of this chapter is to chart the key points in history where political communities (empires, States, international organisations, etc.) have sought to regulate when they can resort to war and to elaborate upon the content of this regulation.

\subsection{ANCIENT GREECE AND ANCIENT ROME}

Ancient civilisations shared little by way of culture and values and their interactions usually occurred within the context of inter-communal trade and competition over resources. Disputes leading to war were therefore frequent and were often fought according to the maxim of total war, which permitted parties to an armed conflict to use all means necessary to defeat and subjugate their opponents. This being said, there is evidence to indicate that ancient civilisations were careful to articulate their justifications for resorting to war. ${ }^{2}$

1 'As long as men and women have talked about war, they have talked about it in terms of right and wrong'; Michael Walzer, Just and Unjust Wars: A Moral Argument with Historical Illustrations (Basic Books, 2006) 3. On the history of the jus ad bellum see generally Joachim von Elbe, 'The Evolution of the Concept of the Just War in International Law' (1939) 33 American Journal of International Law 665; Amos S. Hershey, 'The History of International Relations during Antiquity and the Middle Ages' (1911) 5 American Journal of International Law 901; Nicholas Tsagourias and Nigel D. White, Collective Security: Theory, Law and Practice (Cambridge University Press, 2013) Chapter 1; Yoram Dinstein, War, Aggression and Self-Defence (Cambridge University Press, 2017) Chapter 3.

2 Ian Brownlie, International Law and the Use of Force by States (Clarendon Press, 1963) 3. 
Ancient Greece was divided into a series of autonomous city-States with each being responsible for their own protection. While alliances were common, they did not prohibit war or even place limits on its use. However, city-States did articulate their own conditions for determining when war was just. For example, many city-States regarded war as acceptable only when it was waged to promote the public good and when the decision to prosecute war was taken in consultation with local authorities as well the demos more generally. ${ }^{3}$

The doctrine of just war can be traced back to the early days of the Roman Empire. ${ }^{4}$ The Empire's ability to wage war was governed by the jus fetiale, a body of natural law which ensured that decisions to go to war were pium, that is, they were undertaken with the express or implied authority of the gods. The jus fetiale was administered by the College of Fetiales (priests) and one of its main responsibilities was to determine whether the requirements imposed by this body of law were met and, ultimately, whether the war was just and thus sanctioned by the gods. ${ }^{5}$

As recorded in the work of Marcus Tullius Cicero, the jus fetiale recognised four just causes for war: (i) unauthorised incursion into the Empire's territory; (ii) infractions of the rights of ambassadors; (iii) violations of treaties and alliances; and (iv) military assistance given to an enemy or an attack against an ally. ${ }^{6}$ In essence, wars were just when they responded to a prior or threatened injury against the Empire. Even when a just cause was present, war was permissible only when the Empire had requested satisfaction for the wrong suffered and the opposing party had rejected this offer. Formally, the political institutions of the Empire (initially the Senate, later the Emperor) were not permitted to declare war without the approval of the College of Fetiales. Yet, because religion was subordinated to the interests of the Empire, the reality was that the fetiales were effectively 'agents' of the Empire and 'practically bound to do their bidding'?

3 Tsagourias and White (n. 1) 4-5.

4 James Turner Johnson, Just War Tradition and the Restraint of War: A Moral and Historical Inquiry (Princeton University Press, 2014) xxiv.

5 Alvin Bernstein, 'The Strategy of a Warrior-State: Rome and the Wars against Carthage' in Williamson Murray, MacGregor Knox and Alvin Bernstein (eds), The Making of Strategy, Rules, States, and War (Cambridge University Press, 1994) 64-65.

6 von Elbe (n. 1) 666-667.

7 'The fetiales were mere agents of the Senate, and practically bound to do their bidding; for in Rome religion was the servant and not the master of the state'; Hershey (n. 1) 920 . 


\subsection{MIDDLE AGES}

'Thou shalt not kill' is one of the Ten Commandments decreed by God and early Christians interpreted this covenant as prohibiting the shedding of blood. Early Christians therefore rejected violence in all its forms and for whatever its reason. ${ }^{8}$ Given the Empire's propensity for violence, brutality and excess, Christianity's strict adherence to pacifism alienated it from the Empire and this dislocation is vividly illustrated by the refusal of Christians to enlist as Roman soldiers. ${ }^{9}$

Christianity's commitment to pacifism had lasted for around three centuries when, in the 4th century, Emperor Constantine converted to Christianity. ${ }^{10}$ Over time, Christianity permeated all aspects of the Empire and, eventually, it emerged as the Empire's official religion. The unification of the Empire and Church created an obvious tension between the Church's pacifism on the one hand and the Empire's practical need for war on the other. In short, a stark and difficult theological question was raised: how could the Empire participate in (let alone initiate) war without violating the fundamental precepts of the Christian Church?

In the 5th century, Saint Augustine attempted to resolve this conundrum in his seminal work De Civitate Dei. Drawing upon the jus fetiale, Saint Augustine saw war as a regrettable evil but accepted that it could be waged compliantly with God's will when its cause was just. For Saint Augustine, it was 'the wrong-doing of the opposing party which compels the wise man to wage just wars'11 and thus it was "with the desire for peace that wars are waged'. ${ }^{12}$ In an often-quoted passage, Saint Augustine explained:

Just wars are usually defined as those which avenge injuries, when the nation or city against which warlike action is to be directed has neglected either to punish wrongs committed by its own citizens or to restore what has been unjustly taken by it. Further, that kind of war is undoubtedly just which God Himself ordains. ${ }^{13}$

8 Stephen C. Neff, War and the Law of Nations (Cambridge University Press, 2005) 39-40.

9 Cecil J. Cadoux, The Early Christian Attitude to War: A Contribution to the History of Christian Ethics (George Allen and Unwin Ltd, 1940).

${ }_{10}$ '[T] $\mathrm{T}$ he accession of Constantine terminated the pacifist period in Church history'; Roland H. Bainton, Christian Attitudes towards War and Peace: A Historical Survey and Critical Re-Evaluation (Abingdon Press, 1960) 85.

11 Marcus Dods (ed.), The Works of Aurelius Augustine, City of God, Vol. II (T. \& T. Clark, 1931) para. 12.

12 Ibid., para. 7.

13 Quoted in John Eppstein, The Catholic Tradition of the Law of Nations (Barnes, 1935) 65. 
With the demise of the Roman Empire and the rise of the Holy Roman Empire, theologians refined the just war doctrine. Most notably, in the 13th century, Saint Thomas Aquinas maintained that wars were just when three conditions were met. First, war had to be sanctioned by the sovereign as the responsible leader of the nation (auctoritas principis). Second, war had to be accompanied by a just cause, namely, that those attacked were deserving of this treatment on account of their wrongdoing (causa justa). Third, the decision to resort to war must be animated by the right intention, that is, to advance good and avoid evil (intentio recta). ${ }^{14}$ In formulating his theory of just war, Saint Thomas Aquinas cited heavily the work of Saint Augustine. However, the critical difference in their theories was that, for Saint Augustine, wars were just when their purpose was to punish opponents for objectively wrongful acts, whereas for Saint Thomas Aquinas, wars were just when their aim was to punish evildoers for their subjective guilt.

Attempts to restrict warfare were not confined to Christian Europe. From around the 7th century, Islam spread across the Middle East and, as with the Holy Roman Empire, religious doctrine supplied the conditions for determining when war was permissible. ${ }^{15}$ But Christian and Islamic traditions differed to the extent that Christianity prescribed procedural and substantive rules to determine whether wars were just, whereas with Islam, wars were permissible when they were sanctioned by sharia law. Importantly, sharia law did not describe a code of rules and procedures in the same way that law was understood in the Holy Roman Empire. Instead, sharia law represented an aspiration or ideal whose content was identified by religious leaders after consultation with fiqh (Islamic jurisprudence, such as the Qur'an) and, by adhering to sharia law, Muslims were able to live their lives according to the will of Allah.

During the Middle Ages, a central feature of sharia law was its sharp distinction between Muslims as believers and non-Muslims as non-believers. While Muslims lived in the light of Allah and therefore resided in an abode of peace, non-Muslims were deprived of Allah's blessings and were thus condemned to an abode of war. ${ }^{16}$ Moreover, Islam embraced a commitment to the notion of jihad (holy war), which imposed a religious imperative upon Muslims to covert non-believers to Islam and fold them into the ummah (the Muslim community). ${ }^{17}$ Jihad required Muslims to use military and non-military means to spread Islam to non-believers and the overall objective was to convert the

\footnotetext{
14 Thomas Aquinas, Summa Theologiae, Vol. II-I (Blackfriars, 1964) 12, I.

15 Niaz A. Shah, 'The Use of Force under Islamic Law' (2013) 24 European Journal of International Law 343, 372.

16 Bassam Tibi, 'War and Peace in Islam' in Terry Nardin (ed.), The Ethics of War and Peace (Princeton University Press, 1993) 129.

17 Ibid., 131.
} 
world to Islam and create an abode of perpetual peace..$^{18}$ In reality, this meant that Muslims and non-Muslims were in a permanent state of war - in fact, Islam referred to non-Muslims as harbis, the adjective of the noun of war. However, this condition of war exhibited nuances. Polytheists, for example, were given the choice of converting to Islam or face war, while People of the Book (Christians, Jews and Zoroastrians) were presented with a third option, which allowed them to maintain their religious identity provided they recognised Islam as supreme and paid a tax (jizya).

\subsection{EARLY MODERN PERIOD}

Religious unity within the Holy Roman Empire collapsed during the religious wars of the 16th century. The Reformation period splintered Christianity into different denominations - broadly speaking, Catholicism and Protestantism - and each invoked the doctrine of just war to wage war against the other. ${ }^{19}$ This resulted in a series of violent confrontations between Catholic and Protestant communities within the Empire, culminating in the Thirty Years War (1618-1648). The potential for Catholic and Protestant communities to simultaneously invoke the notion of just war meant that the justification for war had to depart from the idea that wars were prosecuted in order to punish the guilty for their wrongdoing.

Writing during the Thirty Years War, Grotius adopted a teleological approach to war insofar as he conjoined religious ideals and rationality to conclude that wars were just only when necessary to secure justice and create peace. ${ }^{20}$ For Grotius, wars were just when they were fought for the purpose of defence, to vindicate property or rights or to inflict punishment upon a wrongdoer. On this latter point, Grotius admonished rulers who inflicted harm upon their subjects and regarded such conduct as an affront to universally accepted

18 ' $[\mathrm{N}] \mathrm{o}$ mainstream Islamic scholar before the 20th century ever questioned the basic premise that it was the prerogative, indeed the obligation whenever capacity and strength permitted, of the Muslim community to expand its territory through war'; Andrew F. March and Naz K. Modirzadeh, 'Ambivalent Universalism? Jus ad Bellum in Modern Islamic Discourse' (2013) 24 European Journal of International Law 367, 372.

19 Reflecting on the conflicts between Protestants and Catholics, Gentili explains that 'it is the nature of wars for both sides to maintain that they are supporting a just cause'; Alberico Gentili, De Jure Belli Libri Tres, Vol. I, Ch. VI (Clarendon Press, 1933) 31.

${ }^{20}$ On Grotius and just war theory see Johan Olsthoorn, 'Grotius and the Early Modern Tradition' in Larry May (ed.), The Cambridge Handbook of the Just War (Cambridge University Press, 2018). 
standards of human and divine reason. ${ }^{21}$ As such, States were permitted to wage war when necessary to punish foreign rulers for their attacks on human dignity.

The end of the Thirty Years War offered an opportunity to establish a new system of political and legal order within Europe. The Treaty of Westphalia 1648 carved up Europe into a series of territorially defined political communities who were singularly competent to determine their own political and legal affairs. ${ }^{22}$ In this sense, the Treaty of Westphalia played handmaiden to the modern sovereign State. ${ }^{23}$ For many, the Treaty of Westphalia signalled the demise of the just war theory because, as sovereign entities, States were entitled to wage war without having to justify their actions to a higher authority. ${ }^{24}$

The reality was that the invocation of the language of just war did not cease with the adoption of the Treaty of Westphalia. ${ }^{25}$ During the 18th century, for

21 There is also another question, whether a war for the subjects of another be just, for the purpose of defending them from injuries inflicted by their ruler. Certainly it is undoubted that ever since civil societies were formed, the rulers of each claimed some special right over his own subjects ... But if a tyrant ... practices atrocities towards his subjects which no just man can approve, the right of human social connection is not cut off in such a case.

Hugo Grotius, De Jure Belli et Pacis, Libri Tres, Vol. 2, Ch. XXV (Whewell translation, 1853) 438.

22 'The Peace of Westphalia legitimated the right of sovereigns to govern their peoples free of outside interference, whether any such external claim to interfere was based on political, legal or religious principles'; Mark S. Janis, 'Sovereignty and International Law: Grotius and Hobbes' in Ronald Saint J. Macdonald (ed.), Essays in Honour of Wang Tieya (Brill, 1994) 391.

${ }^{23}$ 'In a strict sense, therefore, the history of the modern law of nations begins with the emergence of independent nation-states from the ruins of the medieval Holy Roman Empire, and is commonly dated from the Peace of Westphalia (1648)'; Louis Henkin, Richard C. Pugh, Oscar Schachter and Hans Smit, Cases and Materials on International Law (West Publishing, 1987) xxxiv.

24 Immanuel Gross, 'The Peace of Westphalia' (1948) 42 American Journal of International Law 20. '[I]nternational law has no alternative but to accept war, independently of the justice of its origin as a relation which the parties to it may set up if they choose'; William E. Hall, A Treatise on International Law (Clarendon Press, 1924) 82.

25 In many accounts of the nineteenth century, however, international legal historians write that the rise of positivism and the concept of absolute state sovereignty meant the end of legal restraint on force. In fact, scholars and government officials in Europe as well as North and South America continued to recognize just war theory. Few European governments failed to justify the use of force in terms of some lawful end.

Mary Ellen O'Connell, 'The Just War Tradition and International Law against War: The Myth of Discordant Doctrines' (2015) 35 Journal of the Society of Christian Ethics $33,38$. 
example, Vattel distinguished between the 'voluntary' and 'necessary' law of nations. ${ }^{26}$ The law of nations was voluntary insofar as European States were sovereign equals and, as such, they were prohibited from intervening in each other's internal affairs. The law of nations was necessary because European States recognised that, while they were bound to observe the law and respect each other's sovereign equality, recourse to war was sometimes required. European States therefore established legal doctrines setting out the circumstances in which they could justifiably wage war against one another. For instance, developments in State practice during the 19th century revealed an acceptance among States that resort to war was permissible when necessary to achieve self-defence. ${ }^{27}$ Similarly, States accepted that armed force could be used where it was a reaction to a prior wrong (a doctrine known as armed reprisals). ${ }^{28}$ States were also permitted to intervene in other States where necessary to protect people from oppression and tyranny. ${ }^{29}$ Evidently, it was the language of just war that underpinned these legal rules.

European States used the 'standard of civilisation' to determine when force could be used against the political communities of the New World, an approach which also drew heavily on the just war tradition..$^{30}$ More specifically, European States refused to recognise these communities as sovereign States on the basis that they were 'uncivilised', ${ }^{31}$ that is, they failed to respect the rights of foreigners to life, personal dignity and property and to freedom

26 Emer de Vattel, Le Droit des Gens ou Principes de la loi Naturelle, Appliqués à la Conduite et aux Affaires des Nations et des Souverains, Book II, Preliminaries (Charles G. Fenwick translation, Carnegie Institution of Washington, 1916) paras 1-28.

27 See the diplomatic correspondence between the United States of America and the United Kingdom over the 1837 Caroline incident; Letter of US Secretary of State Daniel Webster dated 24 April 1841, in Caroline Case (1841) 29 British and Foreign State Papers 1137-1138, https://avalon.law.yale.edu/19th_century/br-1842d.asp. For further discussion see Robert Y. Jennings, 'The Caroline and McLeod Cases' (1938) 32 American Journal of International Law 82.

${ }_{28}$ Portugal v. Germany ('the Naulilaa case'), Special Arbitral Tribunal, 31 July 1928 (1927-28) Annual Digest of Public International Law Cases 526.

29 'Whatever one might argue about the contemporary validity of the doctrine of humanitarian intervention, there is no question that during the nineteenth and early twentieth century the doctrine had gained widespread acceptance as a customary principle of international law'; Daniel Wolf, 'Humanitarian Intervention' (1988) 9 Michigan Journal of International Law 333, 335.

30 Gerrit W. Gong, The Standard of 'Civilization' in International Society (Clarendon Press, 1984).

31 'International law has to treat natives as uncivilised. It regulates, for the mutual benefit of the civilised states, the claims which they make to sovereignty over the region and leaves the treatment of the natives to the conscience of the state to which sovereignty is awarded'; John Westlake, Chapters on the Principles of International Law (Cambridge University Press, 1894) 143. 
of travel, commerce and religion. In addition, these communities were deemed uncivilised where they failed to prohibit slavery, piracy, polygamy, infanticide and inhumane penal practices. ${ }^{32}$ Importantly, European States identified these 'barbarous nations' 33 as legitimate targets for reformative action and sought 'to bring home to them the blessings of civilization'. ${ }^{34}$ European States therefore justified their wars against these communities as civilising missions, a practice that became known as the mission civilisatrice. As Lorimer explained during the 19th century:

Colonisation, and the reclamation of barbarians and savages, if possible in point of fact, are duties morally and jurally inevitable; and where circumstances demand the application of physical force, they fall within necessary objects of war. On this ground, the wars against China and Japan, to compel these countries to open their ports, may be defended..$^{35}$

\subsection{THE HAGUE PEACE CONFERENCES}

The turn of the 20th century witnessed greater integration between States within the world order. As States became more tolerant of their political, economic, religious and social differences, the notion of mission civilisatrice was gradually abandoned. ${ }^{36} \mathrm{New}$ attempts to regulate warfare were pursued and the Hague Peace Conferences are notable in this regard. These conferences produced the Hague Conventions 1899 and 1907 and a key objective of these conventions was to codify existing customary rules on the means and methods of warfare (jus in bello). Nonetheless, the jus ad bellum was mentioned to the extent that the Preamble to Hague Convention I 1899 explained that States parties were '[a]nimated by a strong desire to concert for the maintenance of the general peace'. ${ }^{37}$ Moreover, Article I of Hague Convention II 1907 prohibited recourse to armed force to recover contractual debts, except when the

\footnotetext{
32 Gong (n. 30) 14-15.
}

33 James Lorimer, The Institutes of International Law: A Treatise of the Jural Relations of Separate Political Communities (William Blackwood and Sons, 1883) 101.

34 Article VI of the General Act of the Conference of Berlin 1885. See generally Russell Buchan, International Law and the Construction of the Liberal Peace (Hart, 2013) 19-29.

35 Lorimer (n. 33) 28.

36 John A. Hobson, Imperialism: A Study (Spokesman Books, 1902).

37 Preamble to Hague Convention I for the Pacific Settlement of International Disputes 1899. 
debtor State refused to settle the dispute through arbitration or failed to comply with an arbitral award. ${ }^{38}$

Other limitations on the right to use force were included in a series of treaties concluded between the US and 19 other States during 1913-1914 (these were known as the Bryan treaties after their founder, US Secretary of State William Jennings Bryan). According to the Preamble to these treaties, their stated objective was 'to advance the general cause of peace'. Pursuant to this, these treaties contained a common provision requiring States parties to submit their disputes to a conciliation commission and 'not to declare war or begin hostilities' prior to the commission's report, which had to be submitted within a year.

\subsection{LEAGUE OF NATIONS}

The devastation wrought by the First World War provided world leaders with the impetus to devise a new mechanism for maintaining international peace and security. This led to the creation of the Covenant of the League of Nations (LoN) in 1919 and, according to the Preamble to this treaty, member States pledged to 'achieve international peace and security by the acceptance of obligations not to resort to war, by the prescription of open, just and honourable relations between nations, [and] by the firm establishment of the understandings of international law as the actual rule of conduct among Governments'. The LoN sought to achieve these objectives by implementing a system of collective security and the key provisions of this system appear in Articles $10-16$ of the Covenant. ${ }^{39}$

In Article 10, members of the LoN avowed to respect and preserve from external aggression each other's territorial integrity and political independence. Article 11 explained that any war or threat of war must be referred to the LoN and this provision authorised the LoN to take all measures necessary to safeguard the peace of nations. Article 12 imposed an obligation upon members to refer any dispute likely to lead to rupture to arbitration, judicial settlement or inquiry by the Council of the League of Nations. Under Article 12, members also agreed not to go to war for three months after the rendering of an arbitral award, judicial decision or report by the Council. Moreover, Article 12 required that the award of the arbitrators or the judicial decision must be issued within a 'reasonable time', and the Council's report must be delivered within

38 Article I of Hague Convention II Respecting the Limitation of the Employment of Force for Recovery of Contract Debts 1907.

39 Nicholas Tsagourias, 'The League of Nations and Visions of World Order' (2020) 22 International Community Law Review 291. 
six months of the submission of the dispute. According to Article 13, members agreed not to go to war with other members who complied with 'any award or decision that may be rendered'. If the members refused to refer a dispute to arbitration or judicial settlement, Article 15 mandated that they submit the matter to the Council. If the Council adopted a report unanimously (which did not include those States that were party to the dispute), war was prohibited against any member abiding by that report. If the report did not attract unanimous support within the Council, members were entitled to take all measures 'necessary for the maintenance of right and justice', including presumably the right to go to war. Article 16 stipulated that, where a member resorted to war in disregard of its commitments under the LoN, it was deemed to have committed an act of war against all other members. In such a scenario, Article 16 required members of the LoN to sever their trade and financial relations with an aggressor member and to prevent all intercourse between their nationals and between the nationals of the aggressor member and any other State, whether a member of the League or not. Article 16 further explained that the League's Council could 'recommend' to the members what military measures they could take in order to uphold the provisions of the LoN.

The significance of the LoN lies in the fact that it established organs which made decisions on behalf of States on matters relating to international peace and security; put in place a legal framework for collective security thus making collective security a legal institution; made war and its permissibility a legal matter and therefore moved away from the religious or political overtones of just war theory; ${ }^{40}$ made collective security a global institution for preserving peace and security by regarding war on member States as war against all other members; and treated peace as a multifaceted concept rather than just a military one.

These achievements notwithstanding, the LoN suffered from a number of weaknesses. ${ }^{41}$ First, and critically, the LoN did not prohibit war. Instead, the LoN imposed a series of procedural checks that were designed to prevent or delay war among its members.

Second, the regulatory framework implemented by the LoN applied only to those disputes rising to the level of war. During the early 20th century, war was a technical term and described a legal state of affairs. As such, very specific conditions had to be met in order for a state of war to come into existence most notably, at least one of the parties had to manifest an intention to make

40 In this way, the creation of the LoN replaced the concept of bellum justum with bellum legale; Arnold D. McNair, 'Collective Security' (1936) 17 British Yearbook of International Law 150, 154.

${ }^{41}$ Brownlie (n. 2) 59-62. See generally Eduard Benes, 'The League of Nations: Successes and Failures' (1932) 11 Foreign Affairs 68. 
war. ${ }^{42}$ Thus, States were able to avoid the LoN - and in particular its rules and procedures aimed at preventing or delaying war - by refusing to admit that their actions risked or constituted war, even though they threatened or involved considerable inter-State violence. ${ }^{43}$

Third, enforcement action under the LoN was almost completely decentralised and voluntary. ${ }^{44}$ Generally, members of the LoN (rather than one of the League's organs) could decide for themselves whether a violation of the Covenant had occurred and what enforcement action could be taken. Article 16 did require members to sever financial and commercial relations with Covenant-breaking States. However, in the context of military measures, the Council only had the power to recommend what action should be taken against a malefactor; in other words, members were not legally bound to comply with a decision of the Council. ${ }^{45}$

Fourth, although the League's aspiration was to achieve peace through 'the principle of universality, ${ }^{46}$ it failed to attract universal membership. At its zenith, 63 States were members of the LoN. Critically, the US, which was the principal architect of the LoN, did not become a member due to the Senate's refusal to ratify the treaty. Later on, key members withdrew from the League,

42 'The contracting Powers recognize that hostilities between themselves must not commence without previous and explicit warning, in the form either of a declaration of war, giving reasons, or of an ultimatum with conditional declaration of war'; Article 1 of Hague Convention III Relative to the Opening of Hostilities 1907. See generally Quincy Wright, 'When Does War Exist?' (1932) 26 American Journal of International Law 362.

43 [F]rom the legal point of view, the existence of a state of war between two States depends upon their intention and not upon the nature of their acts. Accordingly, measures of coercion, however drastic, which are not intended to create and which are not regarded by the State to which they are applied as creating a state of war, do not legally establish a relation of war between the States concerned.

Report of the Secretary-General of the League of Nations, A. 14. 1927. V. 14, 83.

A Great Power could with impunity conduct military or naval operations against a lesser Power which it did not characterize as war but as a reprisal, pacific blockade, or intervention or which it did not characterize at all, except perhaps negatively or merely pointing to the absence of a state of war. The lesser Power had the right to elect to treat the hostilities as creating a 'state of war' but in practice the lesser Power involved preferred to accept the limited character of the conflict indicated by the absence of war.

Brownlie (n. 2) 39.

44 Tsagourias and White (n. 1) 14.

45 Hans Kelsen, 'Collective Security and Collective Self-Defense under the Charter of the United Nations' (1948) 42 American Journal of International Law 783, 787-788.

46 Georg Schwarzenberger, The League of Nations and World Order (Constable \& Co., 1936) 44. 
including Japan, Germany and Italy, and the Soviet Union was expelled for its aggression against Finland.

The Geneva Protocol was signed in 1924 and its purpose was to amend the LoN and 'plug the gaps' that it had left. ${ }^{47}$ The noteworthy feature of this Protocol was the obligation inscribed in Article 2 according to which the 'signatory States agree in no case to resort to war'. However, members of the League were chary of the Protocol's prohibition on war and States such as the UK failed to ratify it. In the end, the Geneva Protocol never entered into force. $^{48}$

\subsection{KELLOGG-BRIAND PACT}

The General Treaty for Renunciation of War as an Instrument of National Policy was adopted in 1928. This treaty was an initiative between France and the US and it is generally known as the Kellogg-Briand Pact, being named after the French Foreign Minister (Aristide Briand) and the US Secretary of State (Frank Kellogg) who devised it, or the Pact of Paris, taking the name of the city in which it was signed.

The Pact contained three Articles. Under Article 1, States were prohibited from taking 'recourse to war for the solution of international controversies' and they had to renounce war 'as an instrument of national policy in their relations with each other' ${ }^{49}$ According to Article 2, States agreed to settle their disputes 'by pacific means'. Article 3 provided technical rules relating to when the agreement came into force.

The Pact is important because, for the first time in history, it prohibited member States from resorting to war. The Pact therefore represented a 'key turning point' in the international society's efforts to outlaw war and must be seen as a direct response to the failures of the LoN and in particular its failure to prohibit war. ${ }^{50}$ In this sense, the prohibition on war contained in the Pact sat alongside the broader collective security system implemented by the LoN and they thus formed 'complementary parts of a single structure'. ${ }^{51}$

47 Marc Weller, 'Introduction: International Law and the Problem of War' in Marc Weller (ed.), The Oxford Handbook of the Use of Force in International Law (Oxford University Press, 2015) 10.

48 John F. Williams, 'The Geneva Protocol of 1924 for the Pacific Settlement of International Disputes' (1924) 3 Journal of the British Institute of International Affairs 288.

Article 1 Pact of Paris.

Weller (n. 47) 10.

51 Alfred Zimmern, The League of Nations and the Rule of Law, 1918-1935 (Macmillan, 1936) 402. 
Notwithstanding the significance of its implementation of a jus contra bellum (law against war), the Pact suffered from several shortcomings. First, the Pact prohibited recourse to war. While Article 2 required States to settle their disputes peacefully, and while this could be interpreted as imposing a general obligation upon States to employ only peaceful means to resolve their disputes, this provision had be read in light of Article 1, which outlawed war. As a result, the Pact did not curtail the right of States to resort to armed force unless it took the extreme form of war. Indeed, during the interwar period, States often framed their military campaigns as uses of force short of war and, by doing so, they were able to circumvent the prohibition imposed by the Pact. Mussolini, for example, referred to Italy's annexation of Abyssinia as an 'expedition'. ${ }^{52}$ Similarly, in 1931 Japan characterised its military incursion into Manchuria as an 'incident' and a 'crisis'. ${ }^{53}$

Second, the Pact prohibited war as an instrument of national policy, meaning a contrario that war as an instrument of international policy was not covered. According to this line of reasoning, States could wage war where it was pursuant to their religious or ideological goals ${ }^{54}$ and, moreover, they could do so in order to enforce compliance with international law because this was a matter falling beyond national policy. ${ }^{55}$

Third, self-defence was not expressly addressed in the Pact. The travaux préparatoires reveal that the drafters recognised that the right of self-defence was implicitly incorporated into the Pact insofar as the parties agreed that the Pact did not impair the right of States to resort to war where necessary for self-defence. ${ }^{56}$ However, the Pact's failure to set limits on the right of

52 Bernardus V. A. Röling, 'On the Prohibition of the Use of Force' in Anthony Blackshield (ed.), Legal Change: Essays in Honour of Julius Stone (Butterworths, 1983) 274-298.

53 Quincy Wright, 'The Manchurian Crisis' (1932) 26 American Political Science Review 45.

54 Hans Wehberg, The Outlawry of War (Carnegie Endowment for International Peace, 1931) 76.

${ }_{55}$ ' $[\mathrm{A}]$ war which is a reaction against a violation of international law, and that means a war waged for the maintenance of international law, is considered an instrument of international and hence not of national policy'; Hans Kelsen, Principles of International Law (Rinehart and Co., 1952) 43.

56 During negotiations, for example, the US representative explained that self-defence 'is inherent in every sovereign State and is implicit in every treaty. Every nation is free at all times, and regardless of treaty provisions, to defend its territories from attack or invasion, and it alone is competent to decide whether circumstances require recourse to war in self-defence'; US Secretary of State Frank Kellogg, quoted in David H. Miller, The Peace Pact of Paris: A Study of the Briand-Kellogg Treaty (G. P. Putnam's Sons, 1928) 213-214. 
self-defence left room for States to interpret this doctrine broadly and, in doing so, they gradually hollowed out its prohibition on war. ${ }^{57}$

Fourth, and as with the LoN, the Pact of Paris did not attract universal membership. At the outset, 15 States signed the Pact and there were another 48 accessions over the following years. Ultimately, then, a large number of States were unconstrained by the Pact's prohibition on resort to war.

Technically, the Pact of Paris is still in force today. Yet, to all intents and purposes, the Pact became defunct with the signing of the United Nations (UN) Charter.

\subsection{UNITED NATIONS}

By 1945, States' efforts to restrict recourse to war had almost certainly led to the crystallisation of a rule of customary international law prohibiting the use of force. ${ }^{58}$ To a certain extent, developments in customary law were eclipsed by the signing of the UN Charter in 1945. In the ashes of the Second World War, States created a new international organisation and sought to introduce a more sophisticated system of collective security than that of the LoN.

A key objective of the UN is to maintain international peace and security. ${ }^{59}$ To achieve this objective, the Charter's Preamble explains that the UN must seek to eliminate the scourge of war, protect human rights and the dignity and worth of the human person and promote social progress and better standards of life.

Article 2(1) UN Charter makes it clear that the UN is based on the principle of the sovereign equality of its member States. With the purpose of protecting State sovereignty, Article 2(3) UN Charter imposes a duty upon States to resolve their disputes peacefully. ${ }^{60}$ But Article 2(3) does not require States to settle their disputes when they arise - instead, it stipulates that States must only use peaceful means to resolve them. ${ }^{61}$ To reinforce this obligation, Article

\footnotetext{
$57 \quad$ Neff (n. 8) 303-313.

58 'It is submitted that the practice of states between 1920 and 1945, and more particularly between 1928 and 1945, provides adequate evidence of a customary rule that the use of force as an instrument of national policy other than under a necessity of self-defence was illegal'; Brownlie (n. 2) 110. For a different view see W. Michael Reisman, 'Coercion and Self-Determination: Construing Charter Article 2(4)' (1984) 78 American Journal of International Law 642, 642 ('Until 1945, there was no customary international prohibition on the unilateral use of force').

59 Article 1(1) UN Charter.

${ }^{60}$ Anne Peters, 'International Dispute Settlement: A Network of Cooperational Duties' (2003) 14 European Journal of International Law 1.

${ }^{61}$ Richard B. Bilder, 'An Overview of International Dispute Settlement' (1986) 1 Journal of International Dispute Resolution 1.
} 
2(4) UN Charter obliges States to 'refrain in their international relations from the threat or use of force'. Importantly, Article 2(4) prohibits force rather than war and thus seeks to avoid the normative loopholes that beset the LoN and Pact of Paris.

Notwithstanding the prohibition implemented by Article 2(4), the UN Charter recognises two instances in which force can be lawfully used: self-defence and enforcement action. With regard to self-defence, Article 51 UN Charter preserves the right of self-defence enshrined in customary law and subjects it to additional limitations in order to make it suitable for the post-Charter era. In particular, Article 51 requires States to report instances of self-defence to the Security Council (SC) and suspends the right of self-defence where the SC takes measures that are effective at restoring international peace and security.

Moving to enforcement action, Article 24(1) UN Charter confers upon the SC primary responsibility for the maintenance of international peace and security and Article $25 \mathrm{UN}$ Charter provides that decisions of the Council are binding upon all member States. Chapter VI of the UN Charter contains a number of provisions according to which the $\mathrm{SC}$ can make recommendations to member States to assist with the peaceful resolution of disputes. Where the SC determines that a threat to international peace and security exists under Chapter VII of the UN Charter, it can authorise all measures necessary to restore international peace and security including the use of force. In contrast to the LoN, the UN institutes a centralised collective security system with mandatory powers and it is the SC that resides at its apex.

\subsection{CONCLUSION}

Attempts to regulate the use of force date back into antiquity. This chapter has provided an intellectual and historical account of these efforts and it culminated in a presentation of the main features of the UN's collective security system. As effectively all States are members of the UN, the Charter constitutes the lynchpin of the contemporary jus ad bellum. As we shall see as this book progresses, there are a number of challenges relating to the interpretation and application of the UN Charter. Furthermore, while the UN Charter is the main source of the jus ad bellum, other sources exist such as customary law and the law of regional and subregional organisations. These frameworks also raise a host of complex interpretative questions as well as more systemic questions on how they interact with the rules of the UN Charter. It is these issues that will be addressed in the following chapters of this book. 